\title{
Dynamics of zonal halophyte communities in salt marshes in the world
}

\author{
Lee, Jeom-Sook \\ Department of Biology, Kunsan National University, Gunsan \\ 54151, Korea
}

\author{
Kim, Jong-Wook (corresponding author) \\ Department of Biological Science, Mokpo National University, \\ Muan-gun 58554, Korea \\ keco@mokpo.ac.kr
}

Publication Information:

Received 20 March 2018, Accepted 19 April 2018, Available online 30 June 2018

doi: 10.21463/jmic.2018.07.1.06

\begin{abstract}
Understanding of salt marsh plant zonation caused by abiotic and biotic factors is essential for successful conservation plans in the face of ongoing environmental change. The frequency of flooding is more important than elevation in predicting marsh plant zones. Tidal marsh plants are distributed across a wide gradient of soil-water salinities. Studies done to date indicate that redox potential, ionic composition of soil, moisture content of soil, latitude, topographical, and climatic factors may play some role in forming vegetation zones. Competition and facilitation are important in mediating zonation, and the importance of facilitation of plant growth increases with increasing physical stress within the abiotic range limits. A refined understanding of facilitation along stress gradients would help inform successful restoration and management of vegetation. In the salt marsh plant community, a trade-off between belowground competitive ability and the ability to tolerate physical stressors appears to drive plant growth patterns across the landscape. Understanding and predicting shifts between bare flats and vegetated marshes is of great importance, because it provides a useful scientific basis for understanding vegetation zonation. A bimodal distribution of intertidal elevations, positive feedbacks, and alternative stable states and abrupt shifts in elevation from bare flats to vegetated states are present in salt marsh ecosystems. Strategies to assess whether alternative stable states are present are now converging in fields as disparate as desertification, limnology, oceanography, ecology and climatology. Further research should therefore focus on the conditions for and the specific mechanisms behind alternative stable states in salt marsh ecosystems.
\end{abstract}

\section{Keywords}

Salt marsh plant, Zonation, Abiotic factor, Biotic factor, Positive feedback 


\section{Introduction}

Coastal salt marshes are unusual amongst wetland ecosystems around the world (Vince and Snow 1984; Armstrong et al. 1985; Kim and Ryu1985; Kim et al. 1986; Bertness and Ellison 1987; Liet al. 2008; Ko 2001; Moffett et al. 2012; D'Odorico et al. 2013). Their surfaces are regularly flooded with salt water; all salt marsh plant communities are submerged at some time to varying extents and topographical features lead to a greater than normal extent of flooding and drainage. Salt marsh plant communities are discrete, simple systems dominated by only a handful of plant species and consist of recurrent zonation patterns along environmental gradients(Pomeroy and Wiegert 1981; Bertness and Ellison 1987; Kim and Ihm 1988; Serag 1999; Ihm et al. 2007; Kim et al. 2010; Lee et al. 2016).

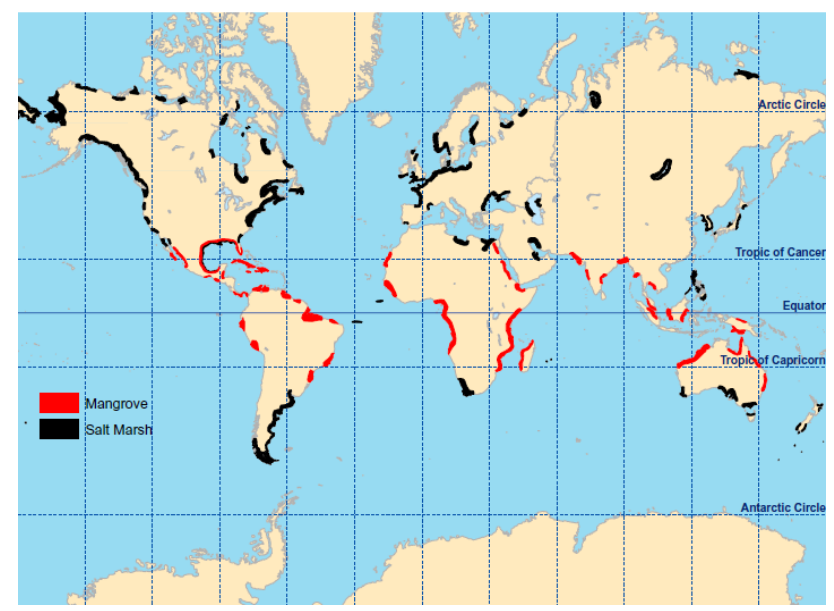

Fig 1. Global distribution of mangroves and salt marshes (D'Odorico et al. 2012).

Upper salt marshes are dominated byhigh salt marsh species such as Juncus roemerianus (Pennings et al. 2005), Iva frutescens (Bertness and Hacker 1994; Emery et al. 2001), Phragmites australis (P. communis) (Min and Kim 1983; Roman et al. 1984; Kim and Ihm 1988; Ihm and Lee 1998), Scirpoides nodosa and Phormium tenax (Partridge and Wilson 1988), Suaeda vera and Lygeum spartum (Rogel et al. 2000, 2001), Frankenia palmeri and Salicornia subterminalis (Zedler et al. 1999), Artemisia maritima (Olff et al. 1988), and Arthrocnemum subterminale (Pennings and Callaway 1996). Lower salt marshes are dominated bylow salt marsh species including Spartina alterniflora (Roman et al. 1984; Pennings et al. 2005), Juncus gerardi (Bertness and Hacker 1994), Sarcocornia quinqueflora and Samolus repens (Partridge and Wilson 1988), Sarcocornia fruticosa and Juncus maritimus (Rogel et al. 2000, 2001), Spartina foliosa (Zedler et al. 1999), Trifolium repens (Olff et al. 1988), Salicornia virginica (Pennings and Callaway 1996), and Suaeda japonica and $S$. maritima (Kim and Ihm 1988; Ihm and Lee 1998).

Physiologically and morphologically, salt marsh plants have developed a number of mechanisms to avoid and resist saline stress; these include salt hairs and salt glands, succulence, dilution of salinity by increased growth, osmotic adjustment, compatible osmotica, root excretion of salts and root molecular sieves,and selective ion uptake (Ungar 1998; Flowers et al. 1977, 1986) 
Early work on zonation focused on the apparent correlation of vegetative patterns with variations in the physical environment (Lee 1990; Woerner and Hackney 1997). Most studies on zonation have been done in middle to high latitudes of the northern hemisphere, in euhaline or periodically hypersaline marshes with regular tides (Costa et al. 2003). Later work focused on salt marsh plant zonation determined by both abiotic and biotic factors. Although abiotic factors may play a significant role in determining which species become established and survive in zonal plant communities in salt marshes, it is also necessary to consider the effect of biotic factors on the formation of plant communities (Table 1). These two elements play a significant part in determining whether or not a species can successfully establish itself in a salt marsh. Comparative studies of the arrangements of the upper and lower zone boundaries might shed light onthe interplay of these factors in determining zonation patterns (Pielou and Routledge 1976; Lee et al. 2016).

Table 1. Upper and lower borders set by biotic and abiotic factors on salt marshes.

\begin{tabular}{|l|l|}
\hline \multicolumn{1}{|c|}{ Lower borders by abiotic factors } & \multicolumn{1}{c|}{ Upper borders by biotic factors } \\
\hline - Elevation & - Competition \\
- Flooding frequency & - Facilitation \\
- Salinity & - Trade-off between competition and facilitation \\
- Redox potential & - Physiological adjustment \\
- Soil ionic composition or pH & - Seedling recruitment \\
- Soil moisture & - Emergence and growth strategy \\
- Latitude & - Grvasion \\
- Topographical factor & - Herbivory \\
○ Debris or wrack & \\
$\circ$ Deposit soil & \\
- Sediment shear-strength & \\
- Climatic factor & \\
$\circ$ Alternating periods of rainfall & \\
$\circ$ El Niño and La Niña & \\
\hline
\end{tabular}

First, there are abiotic factors related to salt marsh plant zonation:

1. Elevation (Sánchez et al. 1996; Bockelmann et al. 2002),

2. Frequency of flooding (Lee 1990; Allison 1996; Pennings et al. 2005),

3. Salinity (Mahall and Park 1976; Kim and Ihm 1988),

4. Redox potential (Howes et al. 1981; Davy et al. 2011),

5. Ionic composition and pH of soil (Rogel et al. 2000; Angiolini et al. 2013),

6. Moisture content of soil (González-Alcaraz et al. 2014; Ihm et al. 2007), 
7. Topographical factors (Morzaria-Luna et al. 2004; Collin et al. 2010),

8. Latitude (Pielou and Routledge 1976; Isacch et al. 2006), and

9. Climatic factors (Rogel et al. 2000; Costa et al. 2003).

Second, there are biotic factors related to salt marsh plant zonation.

1. Competition (Pidwirny 1990; Morris 2006). As in tidal marshes of the northern hemisphere, competition is important in structuring salt marsh plant communities (Silander and Antonovics 1982; Costa et al. 2003).

2. Facilitation (positive interactions, e.g. plant cover alleviating saline stress) (Bertness and Shumway 1993; He et al. 2011). Facilitation is important in mediating the zonation of $T$. chinensis. Within its physiological stress tolerance range, it is limited by plant competition in low-salinity areas, and facilitated by neighbours in habitats where there is high salt stress.

3. Trade-off between competition and facilitation (Levine et al. 1998; Pennings et al. 2005). If nutrient supply dictates competitive dominance across gradients given physical factors, it may control any trade-off between competitive ability and stress tolerance underlying plant zonation (Levine et al. 1998).

4. Physiological adjustment (Cooper 1982; Callaway 1995),

5. Seedling recruitment (Espinar et al. 2005; Engels et al. 2011),

6. Invasion (Beare and Zedler 1987; Castillo et al. 2008),

7. Grazing (Silliman and Zieman 2001; Jutila 1999), and

8. Herbivory (Wolcott and O'Connor 1992; Lenssen et al. 2004).

Finally, positive feedback structures the dynamics of salt marsh plant communities as well as other ecosystems (Wilson and Agnew 1992; van Wesenbeeck 2008; Scheffer 2009; Murphy and Bowman 2012; Wood and Bowman 2012; Wang and Temmerman 2013). Bare and vegetated states are potentially alternative stable landscape states with abrupt shifts between them (Wang and Temmerman 2013). Intermediate elevations with pioneer vegetation patches consist of potentially unstable transient states between the alternative attractors, i.e. lower-elevation bare flats or densely vegetated marshes found at higher elevations. Understanding and predicting transient shifts between bare flats and vegetated marshes is of major importance, because it provides a useful scientific basis for protecting and restoring intertidal flats and marshes and their valuable ecosystem services, in the face of increasing environmental pressures such as the accelerating rise in sea levels.

\section{Abiotic factors}

Determining the mechanisms underlying the growth of organisms has long been a goal of ecological research (Adams 1963; Cui et al. 2011; Guo and Pennings 2012) and it is widely accepted that both abiotic and biotic factors are important in affecting the distribution of different species, but there is no consensus on how the relative role of biotic factors varies given abiotic factors. In salt marsh habitats, most research has centered on the ways in which abiotic factors affect plant zonation (Bertness and Ellison 1987; Kim and Ihm 1988; Sánchez et al. 1996; Ihm and Lee 1998; Zedler et al. 1999; Ko 2001; Silvestri et al. 2005; Alvarez-Rogel et al. 2007; Hladik and Alber 2014): topographical and climatic factors such as elevation, frequency and duration of tidal flooding, the influence of fresh water, distance from the water source (tidal effect), periods of rainfall and drought, disturbance by debris, and physical and chemical factors of soil such as salinity, 
moisture, type, texture, drainage, nutrient toxicity, organic content, depth of the water table, redox potential, peat accumulation, aeration, and sulfide concentration (Table 1).

Elevation of the tidal range is a primary determinant of the environmental factors that affect plant distribution and is the physical basis of the distinctive zonation often reported for the distribution of salt marsh plantspecies and communities(Adams 1963; Sánchez et al. 1996; Bockelmann et al. 2002; Silvestri et al. 2005; Min 2015). Very small differences in elevation are sufficient to alter the intertidal environment (Brereton 1971; Zedler et al. 1999; Davy et al. 2011). Salt marsh plantshelp to bind sediments and root systems promote sediment stabilization and environmental conditions that allow other species to invade the raised surface (Caçador et al. 2007). An increase in marsh elevation causes a decrease in the number of flooding events, which results in increases in redox potential and soil salinity.

Flooding is the primary factor controlling the distribution of salt marsh species. Flooding establishes a strong nonresource stress gradient across salt marshes, with soil anoxia and waterlogging decreasing from the seaward edge to the terrestrial border (Mendelssohn et al. 1981; Woerner and Hackney 1997; Zedler et al. 1999; Cui et al. 2011).

The fact that most positive correlations between flooding frequency and change in species cover occur in the higher regions of salt marshes suggests that this effect occurs mainly when the of flooding-related disturbance is relatively low (Adams 1963; Snow and Vince 1984; Armstrong et al. 1985; Olff et al. 1988). Flooding generally reduces the amount of vegetation cover and may limit plants' distribution ranges by inducing anaerobiosis of the substrate, via deposition of sand and clay, or by the toxic effects of salt. Sedges perform best in water-saturated soil, while other species often prefer half-flooded or well-drained substrata. Instead, optimal growth occurs in half- and fully-flooded soil. Flooding frequency and elevation have a higher value in predicting the occurrence of dominant plant species than does elevation (Snow and Vince 1984; Armstrong et al. 1985; Bertness and Ellison 1987; Sánchez et al. 1996; Rogel et al. 2001; Bockelmann et al. 2002; Cui et al. 2011). The close relationship between flooding frequency and elevation particularly applies to lower elevations, where minor changes in elevation lead to major changes in flooding frequency.

At very high soil elevations, above mean high sea level (MHSL), soil salinity tends to decrease because of less frequent flooding and associated reduced salt input (Phleger 1971; Mahall and Park; 1976; Sánchez et al. 1996; Ihm and Lee 1998; Rogel et al. 2000; 2001; Pennings et al. 2005; Silvestri et al. 2005; Ihm et al. 2007; Angiolini et al. 2013; Cho 2015). This observation, which provides a link between the presence of halophytes and topographic elevation, may be explained by noting that evaporation periods (occurring when the marsh is not flooded) are longer at higher elevations and, thus, salts in surface soils may become very concentrated. Thus, salt marshes exhibit distinct plant growth patterns along salinity gradients (Sánchez et al. 1996; Emery et al. 2001; Pennings et al. 2005; Caçador et al. 2007; Engels et al. 2011).

Redox potential generally increases with increasing tidal height and decreasing tidal flooding. Low redox potential is characteristic of flooded soils and has been shown to inhibit plant growth (Howes et a1. 1981; Mendelssohn et al. 1981; Armstrong et al. 1985; Bertness and Ellison 1987; Davy et al. 2011). Thus, differences in redox potential are important determinants of zonation patterns in salt marshes (Caçador et al. 2007). Salt marsh halophytes differ considerably in their ability to oxygenate rhizospheres (e.g. by the production of aerenchyma) and to tolerate reducing conditions (Colmer and Flowers 2008). Salicornia europaea, an annual halophyte that is regarded as a rapid primary colonist of low marshes in many parts of the northern hemisphere (Ihm and Lee 1998; Davy et al. 2011), can be found over the full range of redox potentials. In contrast, the abundance of Suaeda maritima is low at low redox potentials, regardless of elevation. 
Differences between vegetation zones caused by the $\mathrm{pH}$ of surface sediment are less common, but indirect factors such as organic content accumulation in older marshes and salt deposition/leaching in depressions can produce differences of 1-4 pH units (Vince and Snow 1984; Bertness and Ellison 1987; Costa et al. 2003; Angiolini et al. 2013). Similar ranges of $\mathrm{pH}$ were found in the Pólvora Island marsh and different ranges were found in south-western salt marshes in South Korea, but because of the flat landscape and the large amplitude of daily and seasonal fluctuations in seawater levels, differences between vegetation zones did not persist through time and it is unlikely that they impose distribution limits for the dominant perennials (Ihm and Lee 1998).

The ratios of $\mathrm{Ca}^{2+} / \mathrm{Na}^{+}, \mathrm{Ca}^{2+} / \mathrm{Mg}^{2+}$ and $\mathrm{K}^{+} / \mathrm{Na}^{+}$are decisive in plant zonation in salt marshes, at least in a semiarid Mediterranean climate (Reimann and Breckle 1995; Rogel et al. 2000, 2001). The lowest areas, which are subject to increased flooding, do not coincide with those in which the concentration of salts is highest because the soils in these areas remain wet enough throughout the year to bring about the dilution of salts (Rogel et al. 2001). The habitats occupied by the two most abundant species seem to be very well defined in Mediterranean salt marshes. Juncus maritimus occupies soils with a higher $\mathrm{Ca}^{2+} / \mathrm{Na}^{+}$ratio and a lower $\mathrm{K}^{+} / \mathrm{Na}^{+}$ratio than Schoenus nigricans.

Numerous studies have reported relationships between coastal plant communities and moisture content of the soil (Omer 2004; Ihm et al. 2007; Lee et al. 2007; González-Alcaraz et al. 2014). The distribution of plant species responds to changes in soil moisture and, hence, monitoring of vegetation has been proposed as an effective tool to detect important species in wetlands (Hong 2015). The soil moisture gradient traditionally has been considered one of the most important abiotic factors that affect the plant zonation of salt marshes (Ihm and Lee 1998; Rogel et al. 2000; Ihm et al. 2007). Salicornia herbacea communities are found in areas with low soil water content. The environmental variables that have the greatest influence on the distribution of the dominant salt marsh species $S$. pillansii include soil moisture, distance from the estuary, elevation above mean sea level, and depth of the water table (Bornman et al. 2008). The most important ecological driver for salt marsh vegetation, especially along the arid west coast of southern Africa, is moisture.

It has been suggested that ecohydrological zones, which reflect the combined influences of topographical, sediment, and vegetation heterogeneity, are the fundamental spatial habitat units comprising salt marsh ecosystems (Moffett et al. 2012; Xin et al. 2013).

Vegetation distribution patterns suggest that channel size and distance to the bank are fundamental factors in determining species distribution (Adams 1963; Sanderson et al. 2001; Collin et al. 2010). Tidal creeks control tidal flow into the marsh and, thereby influencing flooding and drainage. Tidal channel networks strongly structure salt marsh plant distributions in Petaluma Marsh in California (Sanderson et al. 2000; Morzaria-Luna et al. 2004). The factors that influence seedling establishment are more favorable along creek edges, and seedling numbers decline with distance from creeks (Hopkins and Parker 1984; Rand 2000).

Ihm et al. (2007) explained a shift in the seaward limit of Suaeda maritima and Halimione portulacoides on the basis of soil texture. Suaeda maritima was independently influenced by sediment shear-strength, exhibiting low abundance on softer sediments, which accords with the tendency of its seedlings to be washed away by tides (Davy et al. 2011). Floating debris is frequently stranded at high elevations, killing underlying vegetation and leaving discrete bare patches (Bertness and Ellison 1987; Bertness et al. 1992). These bare patches are initially colonized by fugitivemarsh plants (pioneer plants) that are displaced by competitively superior perennial turfs (Bertness and Ellison 1987). 
Geographic variations in climate may induce different salinity patterns at different marsh elevations (Pennings et al. 2005; Wang et al. 2007; Cui et al. 2011). In high-latitude marshes on both US coasts, salinity levels in undisturbed vegetation tend to decline from the low to the high marsh (Pennings and Bertness 1999; Pennings and Bertness 2005). In contrast, in low-latitude marshes on both coasts, salinity levels often increase to a peak in the middle or high marsh because of increased evaporation. In low-latitude salt marshes, a hot climate leads to elevated salinities at upper/middle elevations; in high-latitude salt marshes, the climate is much cooler and salinity is relatively low. The difference in salinity between low- and high-latitude salt marshes may generate variations in plant organization and zonation. The most extreme evidence of geographical variation on the role of salinity in mediating salt marsh plant patterns lies in the occurrence of 'salt pans' in low-latitude marshes (Pielou and Routledge 1976; Pennings and Bertness 1999; Pennings et al. 2005). Salt pans, unvegetated expanses of the marsh that occur where soil salinities exceed levels that plants can tolerate, are a common feature of low-latitude marshes.

The mean deviation of the high tide level and yearly amplitude, caused by winds and storms, shows an irregular pattern with a tendency towards clustering in deviations from the normal 18-year nodal tidal cycle of the moon. These clustered yearly deviations can cause fluctuations in the cover or zonation of salt marsh species (Cramer and Hytteborn 1987; Olff et al. 1988). Meanwhile, alternating periods of rainfall, during which salt leaches into the deepest parts of the soil, and periods of drought, when salt is brought to the surface of the soil, bring about an important variation in salinity and plant zonation, both in regards to the quantity and type of salt (Rogel et al. 2000).

Episodes of warming (El Niño) and cooling (La Niña) of surface waters in the eastern tropical Pacific are highly correlated with excessive rainfall and drought, respectively, over the southwestern Atlantic (Coelho et al. 2002; Costa et al. 2003). These events are responsible for a large part of the interannual variability in both the salinity pattern and the flooding frequency of intertidal zones of the Patos Lagoon estuary. Large and small freshwater discharges into the Patos Lagoon estuary are associated with periods of strong El Niño and La Niña events in the Pacific Ocean. Interannual differences in estuarine water level can cause the physical stress gradient to move up and down in elevation, particularly in low- and mid-marsh zones, and a subsequent variation in salt marsh plant zonation.

As sea levels rise, the frequency and duration of high marsh disturbances are expected to increase (Warren and Niering 1993; Reed 1995; Feagin et al. 2010; Hong 2015). The Instituto Geográfico Português reported a mean sea level rise of $1.3 \mathrm{~mm} \mathrm{y}^{-1}$ between 1882 and 2000 in Cascais, near Lisbon. Coastal salt marsh plants are expected to respond to global sea level rise by migrating toward higher elevations (Caçador et al. 2007). Housing, infrastructure, and other anthropogenic modifications are expected to limit the space available for this potential migration.

\section{Biotic factors}

Biotic factors, such as competition, facilitation, etc., may be of particular importance in salt marsh plant zonation (Table 1) (Sánchez et al. 1996). Competition is the struggle to pre-empt limiting resources such as light, water, and nutrients that determine rates of carbon acquisition. Facilitation is the interaction between plants that improves the uptake of limited resources. Up until the last few decades, plant zonation was believed to result primarily from variations in physical and chemical parameters. More recent studies, however, have illustrated the importance of biotic interactions in plant zonation (Pielou and Routledge 1976; Pennings and Callaway 1992; Levine et al. 1998; Castillo et al. 2000; Costa et 
al. 2003). Snow and Vince (1984) were the first to provide experimental evidence that the distribution and zonation of salt marsh species along the tidal flooding gradient was not solely due to physiological restrictions but was also affected by interspecies competition.

Competition and facilitation: Early studies of coastal plant communities demonstrated that competition between species mediates salt marsh plant zonation (Bertness and Ellison 1987; Callaway et al. 1990; Pennings and Callaway 1992;

Engels and Jensen 2010; He et al. 2011) and that facilitation is important in mediating plant performance and diversity in marshes with high salinity/flooding stress (Bertness and Hacker 1994). More recent studies on facilitative and competitive interactions in salt marshes (Pennings et al. 2003) have focused on latitudinal patterns. The Stress-Gradient Hypothesis (SGH) (Bertness and Callaway 1994; Hackney et al. 2010) is one of the most well known and widely tested facilitation hypotheses. The SGH predicts that the importance or intensity of competition and facilitation will change along abiotic stress gradients, with facilitation being more important in high abiotic stress conditions. At lower levels of abiotic stress, competition and consumer pressure become increasingly important determinants of species distribution. The ability of the SGH to predict latitudinal patterns of facilitation, however, is limited by selection-driven differences in intraspecies and interspecies salt tolerance between low- and high-latitude plants (Pennings et al. 2003).

While extremely stressful environments may lie outside of the physiological stress tolerance range (Bruno et al. 2003), Holmgren and Scheffer (2010) recently suggested that the occurrence of strong facilitative effects in mild conditions may be the rule rather than the exception, since in extremely harsh environments facilitative amelioration of conditions could entirely prevent growth.

Stress tolerance influences plant zonation in several ways (Rabinowitz 1978; Snow and Vince 1984; Marcum and Murdoch 1992). Three models based on the interaction of physiological characteristics and interspecies competition have been developed. Zonation of species along an environmental gradient may arise if: (i) each species is physiologically restricted to a different portion of the gradient; (ii) each species performs best in a different portion of the gradient, but tolerance ranges are sufficiently broad that species could grow in other habitats were it not for inadequate dispersal, the presence of competitively superior species, the presence of herbivores, or a combination of these factors; and (iii) all species prefer the same portion of the gradient such that species are displaced along the gradient according to their breadth of tolerance, dispersal, competitive abilities, and susceptibility to herbivory.

The competition-to-stress hypothesis (Guo and Pennings 2012) states that, across estuarine landscapes, plants are excluded from regions of higher salinity by abiotic stress, and plants are excluded from regions of lower salinity by competition (Crain et al. 2004; Engels and Jensen 2010). Brackish marsh plants die when transplanted into higher salinity habitats. In contrast, salt marsh plants performed well in brackish marshes if neighbors were absent, but were suppressed by competition in these habitats.

Salt marsh plants in Korea can be divided into three groups by seasonal growth patterns (Table 1; Lee and Ihm 2004). The first group, represented by Suaeda japonica, is characterized by fast growth in the early stage and slow growth in the later stage. The second group, comprised of Atriplex gmelini and Aster tripolium, shows slow growth in the beginning and then fast growth from the middle to the later part of the cycle. The third group, which includes $S$. asparagoides, shows consistent growth in the early stage and then faster growth later. The fast root growth exhibited by the first group may be an adaptation to unstable environments where floods occurs frequently and inconsistently. The second group is better suited to a relatively stable environment, and the third group thrives in dry and low-salt conditions. Both seasonal growth 
patterns and growth strategies such as growth rate and root/shoot allocation appear to be important determinants of the distribution and zonation of salt marsh plants.

Grime's competitor/stress tolerator/ruderal theory (CSR theory), which concerns the nature of competition under different levels of resource availability, has received considerable attention from plant community ecologists (Emery et al. 2001). The CSR theory of plant life histories classifies plant strategies as competitive, salt stress-tolerant, or ruderal (Grime 1974, 1977; Emery et al. 2001; Lee and Ihm 2004). It predicts that the intensity of competition, or the degree to which the presence of neighbors reduces a population, increases with productivity because of a trade-off between salt stress tolerance and competitive ability. This model further predicts that productive habitats are dominated by competitive species that can grow rapidly and have high resource capture rates, while the slow growth rates and low resource requirements of salt-tolerant plants allow them to persist in stressful, unproductive habitats.

Tilman's resource-ratio hypothesis predicts that competition for nutrients occurs belowground when nutrients are limited, but as productivity increases aboveground competition for light becomes more important (Tilman 1984, 1988; Wilson and Tilman 1993; Wilson and Keddy 1985). Competitive success varies with productivity owing to a tradeoff between belowground and aboveground competitive abilities. Thus, the competitive ability of a species is determined by its relative biomass allocation to roots, stems, and leaves and the ratio of resources available at any given point along a productivity gradient.

Trade-offs between stress tolerance and nutrient competition are a major driving force in zonation of salt-marsh plant communities (Bertness and Ellison 1987; Daleo et al. 2008). Competitive dominants are typically unable to survive in physically harsh environmental conditions (e.g., high salinity, frequent flooding, and low productivity), while stresstolerant but competitively subordinate plants grow in more stressful habitats because they are displaced from benign habitats by dominant competitors (Snow and Vince 1984; Bertness et al. 1992; Levine et al. 1998; Pennings et al. 2005; Guo and Pennings 2012). It has been suggested that nutrient competition controls the dynamics of many plant communities (Tilman 1988; Levine et al. 1998), since nutrient supply has been shown to influence both species composition and competitive dominance. If nutrient supply also dictates competitive dominance across gradients of physical factors, it may control any trade-off between competitive ability and stress tolerance underlying plant zonation.

In areas with limited water availability, physiological adjustments often involve avoidance and tolerance, with most plants using some combination of the two (Touchette et al. 2009). Avoidance responses may include increases in stomatal and cuticular resistance, changes in leaf morphology, and/or changes in leaf orientation. In contrast, tolerance to water stress involves maintaining adequate cell turgor while minimizing metabolic disruptions. Two of the primary mechanisms that contribute to tolerance are changes in tissue elasticity (i.e., bulk elastic modulus, $\varepsilon$ ) and osmotic adjustment involving inorganic ions, carbohydrates, and organic acids (including compatible solutes) (Touchette et al. 2009; Munns and Tester 2008). Field experiments corroborated the assumption that coast-ward distribution of estuarine vegetation is limited by tolerance to physiological stressors in high-salinity marshes (Snow and Vince 1984; van Wijnen et al. 1999; Crain et al. 2004; Naidoo and Kift 2006). Plant performance in salt marsh treatments was not influenced by neighboring vegetation, because transplants died regardless of neighboring vegetation. Therefore, physiological tolerance rather than biotic interactions is responsible for limiting the seaward limits of these species. The perennial forbs Solidago sempervirens and Potentilla anserina were least able to tolerate salt; even when transplanted to brackish marshes, these two species performed poorly regardless of the treatment of their neighbors, indicating that physiological stress limited their viability in intermediate-salinity marshes. 
In estuarine marshes, the majority of species are perennials that predominantly rely on clonal reproduction (Kim and Ihm 1988, Shumway and Bertness 1992; Lee and Ihm 2004; Engels et al. 2011). However, seedling recruitment is particularly important during secondary succession after large-scale disturbances, when bare patches serve as competitor-free refuges for seedlings and other fugitive plants(pioneer plants)(Bertness et al. 1992). Bare patches in salt marshes often become hypersalinic, thereby limiting seedling recruitment (Bertness and Shumway 1992; Crain et al. 2008). Since disturbance (e.g. by tidal currents, wrack deposition, or ice abrasion) is a common feature of estuarine marshes, it is likely that seedling recruitment also plays an important role in generating plant zonation patterns along larger-scale gradients in estuaries. Germination is generally triggered by abiotic factors (Ungar 1978; Engels et al.2011). In salt marshes, seedling emergence may be impeded by high salinity or flooding. Since leaves of small seedlings do not emerge above the water, $\mathrm{O}_{2}$ and $\mathrm{CO}_{2}$ exchange may be hampered,leading to reductions in photosynthesis and respiration. Differences in germination success as well as seedling tolerance and biotic interactions during the emergence and establishment stage may therefore be crucial for generating plant zonation patterns along salt marsh gradients (Noe and Zedler 2000; Lee and Ihm 2004).

Fugitive species (pioneer species) are often restricted to ephemeral habitats that result from disturbance events (Bertness et al. 1992). In New England salt marshes the intertidal landscape is dominated by dense monospecific stands of clonally propagating perennial turfs that form conspicuous zones at different tidal heights. The zonation of perennial turfs in these habitats is primarily driven by competitive processes where competitive subordinates are displaced to lower elevations or to disturbed habitats where they have a refuge from superior competitors (Bertness and Ellison 1987; Bertness 1991a, b).Scirpus maritimus and Spartina densiflora are capable of acting as salt marsh pioneers and persisting in more mature communities (Costa et al. 2003). These two species are certainly generalists and aggressive invaders that, together with Spartina alterniflora, can monopolize habitats, whether the habitats are physically stressful or more benign.

Invasive aliens alter salt marsh spatial zonation (Castillo et al. 2000; Castillo et al. 2008), which is determined by differences in physiological tolerance to abiotic tidal environments among interacting species (Pennings and Callaway 1992; Ungar 1998). Thus, salt marsh invasion by alien plants with high competitive potential poses interesting questions concerning effects on vegetational zonation.

Salt marshes in northwestern Europe are commonly grazed by sheep and cattle (Jensen 1985; Andresen et al. 1990; Tessier et al. 2003). Intensive grazing often results in plant domination by Puccinellia maritima in the lower parts of the salt marshes and by Festuca rubra in the upper parts of the salt marshes. Grazing promotes the establishment of not only perennials like $P$. maritima, but also annuals like Saliconia europaea, although trampling by livestock damages $S$. europaea seedlings.

Several herbivores (grazers, leaf suckers, seed eaters, etc.) utilize Spartina species in salt marshes around the world (Costa et al. 2003). Herbivory by crabs and sheep(Snow and Vince 1984; Wolcott and O'Connor 1992; Crain 2008) frequently limits the growth of grazed plants, and reduces biomass and/or tiller height. Recent findings indicate that herbivores may play a larger role in marsh plant community structure than is generally recognized (Costa et al. 2003). 


\section{Positive feedbacks in salt marsh ecosystems}

Low-energy inter-tidal environments around the world are usually dominated either by salt marshes or bare flats. Salt marshes are typically found at mid to high latitudes (D'Odorico et al. 2012). Shallow coastal environments are dynamic systems that are impacted by the combined effects of global (e.g., climate) and local (e.g., land-use) drivers of change (Mcglathery 2013). Studies of individual subsystems in the landscape (i.e., vegetated marshes, bare flats, oyster reefs and subtidal seagrass meadows) show that biotic feedbacks lead to nonlinear responses to changing conditions (e.g., sea level rise, storms, sedimentation, and nutrient delivery) and to the emergence of bimodal distributions in elevation, threshold, hysteresis, and alternative stable states (van Wesenbeeck 2008; Murphy and Bowman 2012; Mcglathery 2013).

Salt marsh pioneer zones share a number of common features that give them the potential for alternative stable states and abrupt shifts (van Wesenbeeck 2008). They are characterized by a patchy distribution of either dense stands of the cordgrass Spartina anglica or the common reed Phragmites communis, or to existing as un-vegetated intertidal flats inhabited by benthic invertebrates (Min and Kim 1983; Kim et al. 1986; Choung and Kim 1989; Ihm et al. 2007; van Wesenbeeck 2008; Wang and Temmerman 2013; Kim and Lee 2015; Min 2015). Halophytic vegetation is a key stabilizing factor during wave dissipation, rather than a major trapping agent, because the total inorganic deposition flux is largely independent of standing biomass under common supply-limited conditions (Omer 2004; Marani et al. 2010). The organic sediment production associated with halophytic vegetation represents a major contributor to overall deposition changes, thus critically affecting the ability of salt marshes to keep up with high rates of sea level rise. Understanding and predicting shifts between bare flats and vegetated marshes is of the utmost importance, because doing so provides a useful scientific basis for protecting and restoring salt marshes and their valuable ecosystem services in the face of increasing environmental pressures such as accelerating sea level rise (Warren and Niering 1993; Wang and Temmerman 2013).

The following have been reviewed in salt marsh ecosystems: (1) a bimodal distribution of intertidal elevations, (2) positive feedbacks and alternative stable states, (3) abrupt shifts in elevation from bare to vegetated states, (4) a threshold elevation from bare to vegetated states, and (5) hysteresis (Scheffer et al. 2001; Scheffer 2009; Wang and Temmerman 2013).

A bimodal distribution may indicate the existence of alternative stable states in salt marsh zones (Scheffer 2009; van Wesenbeeck 2008; Wang and Temmerman 2013). This means that tidal flats and marshes lie within a different range of elevations, whereas they are less frequent at intermediate elevations. In the salt marsh pioneer zone, a bimodal distribution of both high and low Normalized Difference Vegetation Index (NDVI)-values can be seen, confirming that vegetation mostly occurs with high biomass or not at all. The lack of intermediate NDVI values, corresponding to intermediate amounts of vegetation, implies that the transition between vegetation and bare soil is sharp instead of gradual.

The distribution of alternative stable states of salt marshes is controlled by positive feedbacks between salt marsh plants that modify their environment to their own advantage and by sediment deposition (Scheffer et al. 2001; van 
Wesenbeeck 2008; Wang and Temmerman 2013; Kim and Lee 2015). Five possible outcomes of positive feedback switches were reported (Wilson and Agnew 1992; Adema et al. 2002), all resulting from the bimodal distribution: (1) occurrence of a stable vegetational mosaic, (2) intensification of a vegetational gradient leading to sharp boundaries, (3) delay, or (4) acceleration of succession by displacement or sharpening of temporal boundaries, and (5) a lack of intermediate states because of the impossibility of coexistence of different species. Wang and Temmerman (2013) found that bare and vegetated states are alternative stable landscape states which shift abruptly. Intermediate elevations with pioneer vegetation patches are an unstable transient state between the alternative attractors, i.e. lowerelevation bare flats or densely vegetated marshes found at higher elevations. The positive feedbacks between vegetation and sedimentation is important because it causes threshold behavior, which means that a small interference may result in a huge shift in the state of the ecosystem. The concept of alternative stable states can be used to approximate ecosystem dynamics on short temporal and spatial scales, but it is unable to predict the long-term dynamics of heterogeneous salt-marsh ecosystems because of spatial feedback processes that occur on a much broader scale (van Wesenbeeck 2008). Increased sediment deposition increases surface elevation, thereby lowering inundation frequency and increasing nutrient availability. These changes improve conditions for plant growth, constituting a positive feedbacks between the density or biomass of Spartina and its growth potential (Wilson and Agnew 1992; van Wesenbeeck 2008).

Although ecosystems generally respond smoothly to gradual changes in environmental conditions, abrupt shifts may occur when a critical threshold condition is exceeded (Scheffer et al. 2001; Wang and Temmerman 2013). The identification of alternative stable states in a specific ecosystem has important implications for the functioning and management of that ecosystem.

Hysteretic behavior arises in the Spartina-dominated case and in other plant communities (in which biomass production is maximum at mean sea level and decreases to zero at mean high water level) (Marani et al. 2010; Scheffer et al. 2001). Wang and Temmerman (2013) provided evidence of bimodality, abrupt shifts, positive feedback, and threshold behavior, which indicate the existence of alternative stable states. More conclusive evidence would require study of the transition from a vegetated to a bare state and further demonstration of the existence of hysteresis, i.e., that the forward and backward shifts between ecosystem states happen in different critical conditions (Scheffer 2009; Scheffer et al. 2001; Wang and Temmerman 2013). The concept of alternative stable states may be applicable to the salt marsh pioneer zone, but is only relevant on short temporal and spatial scales. It is unable to predict the long-term dynamics of heterogeneous salt marsh pioneer zones (van Wesenbeeck 2008).

The occurrence of thresholds, brought about by positive feedbacks, indicates the potential for abrupt shifts, where a slight change in environmental parameters or a slight disturbance brings about a very large change (van Wesenbeeck 2008). Transplanting Spartina anglica plants into three geographically different marshes illustrated that a biomass threshold limits the establishment of Spartina patches, potentially explaining their patchy distribution. The presence of biomass thresholds is evidence for the presence of alternative stable states in small, within-patch scales and short time scales. Criteria for detecting alternative stable states can provide useful tools for detecting the presence of thresholds in ecosystem development. 


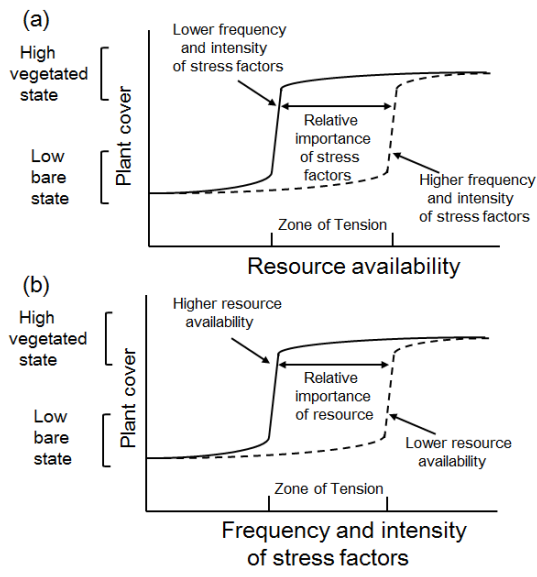

Fig 2. Model of the combined effects of resource availability and stress factors (e.g. salinity, flooding, sediment supply, tidal range, sea level rise rate, wave, and climate) on plant cover in salt marshes. There are two representations of the same model: (a) plant cover is shown as a function of resource availability; (b) plant cover is shown as a function of stress factors (soil water potential, etc.). Alternative stable states of highly vegetated and bare flats exist under the same external environmental conditions (zone of tension) depending on the frequency and intensity of stress factors. Abrupt transitions from highly vegetated salt marshes to bare flats or vice versa can occur under threshold resource conditions or because of disturbance by stress factors.

\section{Conclusions}

\section{Abiotic factors}

The general mechanisms producing plant zonation patterns in coastal salt marshes may be universal, as suggested by many studies, but the importance of particular factors is likely to vary geographically because of variations in the physical environment (Pennings et al. 2005). To determine if (i) each species performs best in a different portion of the gradient or (ii) all species prefer the same portion of the gradient, experimental work in the field and in the laboratory must be carried out (Benito et al. 1990). Understanding of salt marsh plant zonation is essential for successful conservation and restoration plans in the face of ongoing environmental change (Min and Kim 1999; Engels and Jensen 2010; Cui et al. 2011). Our study results indicate that salt marsh plants tend to cluster into various vegetation groups because of the combination of 14 abiotic and 9 biotic factors, and positive feedback.

Flooding frequency and time are more important than shore height in predicting marsh plant zonation; using more flood meters and calculating flooding duration instead of frequency might decrease the uncertainty in the ability to predict flooding within a single plant community (Hinde 1954; Bockelmann et al. 2002).

Second, in addition to the pronounced roles of flooding and salinity in mediating vegetation zonation, this study indicates that soil moisture content may play some role in producing plant zonation in the Yellow River estuary (Cui et al. 2011).

Third, salt marsh plants are distributed across a gradient of soil moisture and salinity (e.g., tidal variations) (Pennings et al. 2005; Touchette 2006; Cho 2015). Plants found in lower marshes, which are exposed to the greatest salinities, must 
generate lower tissue $\psi$ (water potential) if they are to effectively uptake water from the environment. To accomplish this, lower-marsh plants have modified stomatal architectures (larger and more numerous stomates), more ridged tissues (as indicated by higher bulk elastic modulus values, $\epsilon$ ), and increased compatible solute concentrations (as indicated by decreases in $\left.\psi_{\pi}\right)$.

Fourth, geographical variations in the physical environment must be taken into account in order to successfully generalize the results of field studies across geographical areas (Pennings et al. 2005).

Fifth, the various zonation patterns are related to spatial heterogeneities in soil properties and to the interplay between evapotranspiration patterns and subsurface water flow (Silvestri et al. 2005).

\section{Biotic factors}

First, competition and facilitation are important in mediating plant zonation, and that the importance of facilitation increases with increasing physical stress within abiotic range limits (He et al. 2011). A refined understanding of facilitation along stress gradients would help inform successful restoration and management of vegetation.

Second, in the salt marsh plant community, a trade-off between belowground competitive ability and the ability to tolerate the physical stressors of the marsh appears to drive plant zonation patterns across the salt marsh landscape (Emery et al. 2001). Comparing studies of salt marsh plant communities conducted at low and high latitudes suggests that the basic trade-off between competition and stress tolerance that creates zonation patterns is universal (Pennings et al. 2005).

Third, while the response of Spartina alterniflorato high salinity is related tosalt tolerance and thereby allows the plants to reside in prevailing conditions indefinitely, the response of Juncus roemerianus was primarily salt-avoidant which, in the absence of any further physiological adjustment, would likely limit the amount of time an individual plant could survive under stressful conditions (Silvestri 2005). The physiological responses are consistent with observed zonation patterns in these plants.

Fourth, the mechanisms leading to the development of marsh zonation patterns along estuarine salinity gradients begin taking effect during a very early stage of plant development, i.e. the early seedling establishment phase (Engels et al. 2011).

Fifth, grazing causes significant disturbances in salt marsh plant zonation which greatly influence the demography of Salicornia europaea seedlings and result in the dominance of the perennial Puccinellia maritima in low-elevation marshes (Marc et al. 2003).

Sixth, Spartina densiflora alters native zonation patterns via invasion of Spartina maritima tussocks into areas that should be occupied by native species (Castillo et al. 2008). However, S. densiflora invasion seems to be limited by the presence of indigenous cordgrass at lower elevations. These observations support the general theory of salt marsh zonation: competitive dominants, such as $S$. densiflora, colonize higher elevations, displacing competitive subordinates, such as $S$. maritima, to more stressful environments with long submergence periods or higher salinities. 
We suggest seven strategies to aid researchers in monitoring, conserving, and restoring salt marsh ecosystems.

First, despite the evidence pointing to the importance of soil ionic composition in salt marsh plant zonation, reciprocal transplant, laboratory, and greenhouse experiments are needed to demonstrate a cause and effect relationship (Pennings and Callaway 1992; Rogel et al. 2000; Pennings and Bertness 2005; Cho 2015; Hong 2015). Because of the high number of variables, the number of species and geographic locations will be limited.

Second, further studies on aeration conditions at soil depths affected by multiple constituent tides is needed to better understand vegetation zonation (Xin et al. 2010).

Third, some species can be used as bioindicators of the type of salts found in soil (Rogel et al. 2000; Crooks et al. 2002). Knowing the preferences/limitations of native halophyte species may prove advantageous when attempting to restore degraded areas or when introducing resistant species as a source of fodder or forage.

Fourth, reclaimed land is tentatively being opened to the sea via breaching or suppression of dykes, in an effort to restore salt marshes (Daiber 1986; Dausse 2008). The establishment of a target community in a restoration site depends on the presence of seeds at the site as a seed bank or their dispersal to the site. The presence of a target community nearby has been shown to facilitate the restoration process in salt marshes.

Fifth,the presence of Spartina is a major problem faced by managers of coastal habitats, as Spartina colonizes estuarine mud flats and accelerates the process of salt marsh development through increased sediment accretion (Huckle et al. 2000). Recently, expansion by natural mechanisms has been exacerbated by anthropogenic introduction of Spartina anglica and $S$. alterniflora to the extent that Spartina spp. are present in salt marshes across the globe; their expansion should be prevented.

Sixth, planting recommendations should be based on data from the elevational distributions of marsh plants (Zedler et al. 1999;Laegdsgaard2006; Myeong et al. 2011; Cho 2015). It is recommend that species are planted based on their natural elevation of occurrence, rather than in the full range of elevations where the plants can be found. Transplantation is often a costly process, because many sites have limited resources or limitations on establishment.

\section{Positive feedbacks}

In order to predict, conserve, and restore the dynamics of salt marsh communities via positive feedbacks, the following conclusions and suggestions should receive particular attention in the future:

First, it is suggested that abrupt shifts can be attributed to alternative stable states (Beisner et al. 2003; Scheffer 2009; Murphy and Bowman 2012). Verifying the diagnosis of abrupt shifts is important because it implies a radically different view on management options and on the potential effects of global climate change on salt marsh ecosystems. It implies that gradual changes in temperature or other factors might have little effect until a threshold is reached, at which point abrupt shift occur that might be difficult to reverse. While early warning indicators of thresholds for abrupt state change may exist, for most coastal systems it is difficult to know what the leading indicators are or how to quantify them (Mcglathery 2013). Forecasting the resilience of coastal ecosystems and the landscape-scale response to environmental 
change in the next century requires an understanding of nonlinear dynamics, coupled evolution, and early warning signs of tipping points for abrupt state changes.

Second, experiments can be a powerful way to show that salt marsh ecosystems have alternative stable states. There are obvious limitations to researching large spatial scales and long time spans. However, small and quickly-changing systems, which are more experimentally tractable, can help researchers to infer what might happen in larger and more slowly-changing ones (Scheffer 2009). Exploration of small-scale processes, and especially the presence of small-scale thresholds, is helpful in adequate conservation and restoration of salt marsh ecosystems (van Wesenbeeck 2008). In a system that is clearly in flux when viewed on larger spatial and temporal scales, typical characteristics of alternative stable states can be revealed on smaller scales.

Third, given the difficulty of observing positive feedbacks in space and time with field data, simulations can be used to try to understand the effects of feedbacks between spatial patterns and dynamics (Wilson and Agnew 1992; Malanson et al. 2011; Malanson et al. 2001).

Fourth, strategies to assess whether alternative stable states are present are now converging in fields as disparate as limnology, oceanography, ecology, and climatology (Scheffer 2009), and their results can be applied in the future.

In a world experiencing dramatic anthropogenic changes in environmental conditions and severe climatic perturbations, the presence of alternative stable states may have serious and unexpected consequences (Schröder et al. 2005). Further research should therefore focus on the specific mechanisms behind alternative stable states in salt marsh ecosystems.

\section{Acknowledgements}

Our thanks are due to Prof. Ihm Byung-Sun (a professor emeritus at Mokpo National University, Korea) for his encouragement on this work. This research was supported in part by Research Funds of Mokpo National University in 2016.

\section{References}

Adams DA. (1963) Factors influencing vascular plant zonation in North Carolina salt marshes. Ecology44:445-456.

Adema EB., Grootjans AP., Petersen J, Grijpstra J. (2002) Alternative stable states in a wet calcareous dune slack in The Netherlands. J Veg Sci 13:107-114.

Allison SK. (1996) Recruitment and establishment of salt marsh plants following disturbance by flooding. Am Midl Nat136:232-247.

Alvarez-Rogel J, Jiménez-Cárceles FJ, Roca MJ, Ortiz R. (2007) Changes in soils and vegetation in a Mediterranean coastal salt marsh impacted by human activities. Estuar Coast Shelf S 73:510-526.

Andresen H, Bakker JP, Brongers M, Heydemann B, Irmler U. (1990) Long-term changes of salt-marsh communities by cattle grazing. Vegetatio 89:137-148. 
Angiolini C, Landi M, Pieroni G, Frignani F, Finoia MG, Gaggi C. (2013) Soil chemical features as key predictors of plant community occurrence in a Mediterranean coastal ecosystem. Estuar Coast Shelf S 119:91-100.

Armstrong W, Wright EJ, Lythe S, Gaynard TJ. (1985) Plant zonation and the effects of the spring-neap tidal cycle on soil aeration in humber salt marsh. J Ecol 73:323-339.

Beare PA, Zedler JB. (1987) Cattail invasion and persistence in a coastal salt marsh: the role of salinity reduction. Estuar Coast10:165-170.

Beisner BE, Haydon DT, Cuddington K. (2003) Alternative stable states in ecology. Front Ecol Environ1:376-382.

Benito I, Agirre A, Onaindia M. (1990) Zonation of halophytic vegetation along a tide exposure gradient and associated processes. Anales de Biología 16:163-175.

Bertness MD, Shumway SW. (1993) Competition and facilitation in marsh plants. Am Nat 142:718-724.

Bertness MD, Ellison AM. (1987) Determinants of pattern in a New England salt marsh plant community. Ecol Monogr 57:129-147.

Bertness MD, Callaway R. (1994) Positive Interactions in Communities. Trends Ecol Evol9:191-193.

Bertness MD, Hacker SD. (1994) Physical stress and positive associations among marsh plants. Am Nat144:363-372.

Bertness MD. (1991a) Interspecific interactions among high marsh perennials in a New England salt marsh. Ecology72:125-137.

Bertness MD. (1991b) Zonation of Spartina patens andSpartina alterniflora in a New England salt marsh. Ecology72:138-148.

Bertness MD, Gough L, Shumway SW. (1992) Salt tolerances and the distribution of fugitive saltmarsh plants. Ecology73:1842-1851.

Bockelmann AC, Bakker JP, Neuhaus R, Lage J. (2002) The relation between vegetation zonation, elevation and inundation frequency in a Wadden Sea salt marsh. Aquat Bot73:211-221.

Bornman TG, Adams JB, Bate GC. (2008) Environmental factors controlling the vegetation zonation patterns and distribution of vegetation types in the Olifants Estuary, South Africa. S Afr J Bot 74:685-695.

Brereton AJ. (1971) The structure of the species populations in the initial stages of salt-marsh succession. J Ecol59:321-338.

Brown SC. (1998) Remnant seed banks and vegetation as predictors of restored marsh vegetation. Can J Bot76:620-629.

Bruno JF, Stachowicz JJ, Bertness MD. (2003) Inclusion of facilitation into ecological theory. Trends Ecol Evol 18:119-125.

Caçador I, Tibério S, Cabral HN. (2007) Species zonation in Corroios salt marsh in the Tagus estuary (Portugal) and its dynamics in the past fifty years. Hydrobiologia 587:205-211.

Callaway RM, Jones S, Ferren WR, Parikh A. (1990) Ecology of a mediterranean climate estuarine wetland at Carpinteria, California: plant distribution and soil salinity in the upper marsh. Can J Bot 68:1139-1145.

Callaway RM. (1995) Positive interactions among plants. Bot Rev 61:306-349.

Castillo JM, Mateos-Naranjo E, Nieva FJ, Figueroa E. (2008) Plant zonation at salt marshes of the endangered cordgrass Spartina maritima invaded by Spartina densiflora. Hydrobiologia 614:363-371.

Castillo JM, Fernandez-Baco L, Castellanos EM, Luque CJ, Figueroa ME, Davy AJ. (2000) Lower limits of Spartina densiflora and S. maritima in a Mediterranean salt marsh determined by different ecophysiological tolerances. J Ecol88:801-812.

Cho JS. (2015) The distribution, growth characteristic and genetic diversities of Phragmites australis communities in Korea. PhD Dissertation. Mokpo National University, Korea.

Choung Y-S, Kim J-H. (1989) Clonal growth and shoot modules dynamics of Phragmites longivalvis in a reclaimed land. J Ecol Environ 12:171182. 
Coelho CAS, Uvo CB, Ambrizzi T. (2002) Exploring the impacts of the tropical Pacific SST on the precipitation patterns over South America during ENSO periods. Theor Appl Climatol71:185-197.

Collin A, Long B, Archambault P. (2010) Salt-marsh characterization, zonation assessment and mapping through a dual-wavelength LiDAR. Remote Sens Environ 114:520-530.

Colmer TD, Flowers TJ. (2008) Flooding tolerance in halophytes. New Phytol179:964-974.

Cooper A. (1982) The effects of salinity and waterlogging on the growth and cation uptake of salt marsh plants. New Phytol 90:263-275.

Costa CSB, Marangoni JC, Azevedo AMG. (2003) Plant zonation in irregularly flooded salt marshes: relative importance of stress tolerance and biological interactions. J Ecol 91:951-965.

Crain CM. (2008) Interactions between marsh plant species vary in direction and strength depending on environmental and consumer context. J Ecol96:166-173.

Crain CM, Albertson LK, Bertness MD. (2008) Secondary succession dynamics in estuarine marshes across landscape-scale salinity gradients. Ecology89:2889-2899.

Crain CM, Silliman BR, Bertness SL, Bertness MD. (2004) Physical and biotic drivers of plant distribution across estuarine salinity gradients. Ecology85:2539-2549.

Cramer W, Hytteborn H. (1987) The separation of fluctuation and long-term change in vegetation dynamics of a rising sea shore. Vegetatio 69:157-168.

Crooks S, Schutten J, Sheern GD, Pye K, Davy AJ. (2002) Drainage and elevation as factors in the restoration of salt marsh in Britain. Restor Ecol10:591-602.

Cui B-S, He Q, An Y. (2011) Community structure and abiotic determinants of salt marsh plant zonation vary across topographic gradients. Estuar Coast 34:459-469.

Daiber FC. (1986) Conservation of tidal marshes. Van Nostrand Reinhold Company, New York.

Daleo P, Alberti J, Canepuccia A, Escapa M, Fanjul E, Silliman BR, Bertness MD, Iribarne O. (2008) Mycorrhizal fungi determine salt-marsh plant zonation depending on nutrient supply. J Ecol96:431-437.

Dausse A, Bonis A, Bouzillé J-B, Lefeuvre J-C. (2008) Seed dispersal in a polder after partial tidal restoration: Implications for salt-marsh restoration.Appl Veg Sci 11:3-12.

Davy AJ, Brown MJH, Mossman HL, Grant A. (2011) Colonization of a newly developing salt marsh: disentangling independent effects of elevation and redox potential on halophytes. J Ecol 99:1350-1357.

D'Odorico P, He Y, Collins S, De Wekker SFJ, Engel V, Fuentes JD. (2013) Vegetation-microclimate feedbacks in woodland-grassland ecotones. Global Ecol Biogeogr22:364-379.

Emery, NC, Ewanchuk PJ, Bertness MD. (2001) Competition and salt-marsh plant zonation: Stress tolerators may be dominant competitors. Ecology 82:2471-2485.

Engels JG, Rink F, Jensen K. (2011) Stress tolerance and biotic interactions determine plant zonation patterns in estuarine marshes during seedling emergence and early establishment. J Ecol 99:277-287.

Engels JG, Jensen K. (2010) Role of biotic interactions and physical factors in determining the distribution of marsh species along an estuarine salinity gradient. Oikos119:679-685.

Espinar JL, García LV, Clemente L. (2005) Seed storage conditions change the germination pattern of clonal growth plants in Mediterranean salt marshes. Am J Bot 92:1094-1101. 
Feagin RA, Luisa Martinez M, Mendoza-Gonzalez G, Costanza R. (2010) Salt marsh zonal migration and ecosystem service change in response to global sea level rise: a case study from an urban region. Ecol Soc15:14.

Flowers TJ, Troke PF, Yeo AR. (1977) The mechanisms of salt tolerance in halophytes. Ann Rev Plant Physiol 28:89-121.

Flowers TJ, Colmer TD. (2008) Salinity tolerance in halophytes. New Phytol 179, 945-963.

González-Alcaraz MN, Jiménez-Cárceles FJ, álvarez Y, álvarez-Rogel J. (2014) Gradients of soil salinity and moisture, and plant distribution, in a Mediterranean semiarid saline watershed: a model of soil-plant relationships for contributing to the management. Catena 115:150-158.

Grime JP. (1974) Vegetation classification by reference to strategies. Nature 250:26-31. http://dx.doi.org/10.1038/250026a0

Grime JP. (1977) Evidence for the existence of three primary strategies in plants and its relevance to ecological and evolutionary theory. Am Nat 111:1169-1194.

Grime JP. (1979) Plant strategies and vegetation processes. John Wiley \& Sons, Chichester, UK.

Guo H and Pennings SC. (2012) Mechanisms mediating plant distributions across estuarine landscapes in a low-latitude tidal estuary. Ecology93:90-100.

He Q, Cui B, An Y. (2011) The importance of facilitation in the zonation of shrubs along a coastal salinity gradient. J Veg Sci 22:828-836.

Hladik C, Alber M. (2014) Classification of salt marsh vegetation using edaphic and remote sensing-derived variables. Estuar Coast Shelf S 141: 47-57.

Hinde HP. (1954) The vertical distribution of salt marsh phanerogams in relation to tide levels. Ecol Monogr 24:209-225.

Holmgren M and Scheffer M. (2010) Strong facilitation in mild environments: the stress gradient hypothesis revisited. J Ecol 98:1269-1275.

Hong MG. (2015) Effects of freshwater inflow, salinity, and water level on the growth of common reed in salt marsh. PhD Dissertation. Seoul National University, South Korea.

Hopkins DR, Parker VT. (1984) A study of the seed bank of a salt marsh in northern San Francisco Bay (USA). Am J Bot 71:348-355.

Howes BL, Howarth RW, Teal JM, Valiela I. (1981) Oxidation-reduction potentials in a salt marsh: spatial patterns and interactions with primary production. Limnol Oceanogr 26:350-360.

Huckle JM, Potter JA, Marrs RH. (2000) Influence of environmental factors on the growth and interactions between salt marsh plants: effects of salinity, sediment and waterlogging. J Ecol88:492-505.

Ihm BS, Lee JS, Kim JW, Kim JH. (2007) Coastal plant and soil relationships in the southwestern coast of South Korea. J Plant Biol 50:331-335. Ihm BS, Lee JS. (1998) Soil factors affecting the plant communities of wetland on southwestern coast of Korea. Kor J Ecol 21:321-328.

Ihm BS, Lee JS. (2004) Growth strategies of four salt marsh plants on Mankyung River estuary in Korea. Ecol Res19:37-42.

Isacch JP, Costa CSB, Rodríguez-Gallego L, Conde D, Escapa M, Gagliardini DA, Iribarne O0. (2006) Distribution of saltmarsh plant communities associated with environmental factors along a latitudinal gradient on the south-west Atlantic coast. J Biogeogr 33:888-900.

Jensen A. (1985) The effect of cattle and sheep grazing on salt marsh vegetation at Skallingen, Denmark. Vegetatio 60:37-48.

Jutila H. (1999) Effect of grazing on the vegetation of shore meadows along the Bothnian Sea, Finland. Plant Ecol 140:77-88.

Kim CS, Ihm BS. (1988) Studies on the vegetation of the salt marsh in the southwestern coast of Korea. Kor J Ecol 11:175-192.

Kim J-H, KJ Cho, HT Mun, BM Min. (1986) Production dynamics of Phragmites longivalvis, Carex scabrifolia and Zoysia sinica stand of a sand bar at the Nagdong river estuary. Korean J Ecol 9:59-71.

Kim J-W, Lee J-S. (2015)Dynamics of alpine treelines: positive feedbacks and global, regional and local controls. J Ecol Environ 38:1-14. 
Kim JH, Ryu B-T. (1985) Energy flow in a coastal salt marsh ecosystem. Korean J Ecol 8:153-161.

Kim D, Cairns DM, Bartholdy J. (2010) Environmental controls on multi-scale spatial pattern of salt marsh vegetation. Phys Geogr31:58-78. Ko C-H. (2001) The Korean tidal flat: environment, biology and human. Seoul National University Press, Seoul.

Laegdsgaard P. (2006) Ecology, disturbance and restoration of coastal saltmarsh in Australia: a review. Wetl Ecol Manag 14:379-399.

Lee J-S. (1990) On establishment of halophytes along tidal level gradient at salt marshes of Manhyong and Dongjin river estuaries. PhD Dissertation. Seoul National University, South Korea.

Lee J-S, Ihm B-S, Lee J-S, Son D-Y, Kim J-W. (2007) Soil particle sizes and plant communities on coastal dunes. J Plant Biol 50:475-479.

Lee J-S, Kim J-W, Lee SH, Myeong H-H, Lee J-Y, Cho JS. 2016. Zonation and soil factors of salt marsh halophyte communities. J Ecol Envron 40(1): 1-4. doi 10.1186/s41610-016-0010-3.

Lenssen JPM, Menting FBJ, van der Putten WH. (2004) Do competition and selective herbivory cause replacement of Phragmites australis by tall forbs. Aquat Bot 78:217-232.

Levine JM, Brewer JS, Bertness MD. (1998) Nutrients, competition and plant zonation in a New England salt marsh. J Ecol 86:285-292.

Li W-Q, Liu X-J, Khan MA, Gul B. (2008) Relationship between soil characteristics and halophytic vegetation in coastal region of North China. Pak J Bot 40:1081-1090.

Mahall BE, Park RB. (1976) The ecotone between Spartina foliosa Trin. and Salicornia virginica L. in salt marshes of northern San Francisco Bay. II. Soil water and salinity. J Ecol 64:793-809.

Malanson GP, Resler LM, Bader MY, Holtmeier FK, Butler DR, Weiss DJ, Daniels LD, Fagre DB. (2011) Mountain treelines: a roadmap for research orientation. Arct Antarct Alp Res43:167-177.

Malanson GP, Xiao N, Alftine KJ. (2001) A simulation test of the resource-averaging hypothesis of ecotone formation. J Veg Sci 12:743-748.

Marani M, D'Alpaos A, Lanzoni S, Carniello L, Rinaldo A. (2010) The importance of being coupled: Stable states and catastrophic shifts in tidal biomorphodynamics. J Geophys Res 115:F04004.

Marc T, Jean-Paul V, Annie O, Jean-Claude G, Jean-Claude L. (2003) Vegetation dynamics and plant species interactions under grazed and ungrazed conditions in a western European salt marsh. Acta Oecol24:103-111.

Marcum KB, Murdoch CL. (1992) Salt tolerance of the coastal salt-marsh grass, Sporobolus virginicus (L.) Kunth. New Phytol120:281-288.

McGlathery KJ, Reidenbach MA, D’Odorico P, Fagherazzi S, Pace ML, Porter JH. (2013) Nonlinear dynamics and alternative stable states in shallow coastal systems. Oceanography 26:220-231.

Mendelssohn LA, McKee KL, Patrick WH. (1981) Oxygen deficiency in Spartina alterniflora roots: metabolic adaptation to anoxia. Science 214:439-441.

Min BM. (2015) Distribution properties of Phragmites australis and Phacelurus latifoilus in the tidal-flat of Suncheon Bay. J Ecol Environ 38:5765.

Min BM, Kim J-H. (1983) Distribution and cyclings of nutrients in Phragmites communis communitiies of a coastal salt marsh. Korean J Bot 26:17-32.

Min BM, Kim J-H. (1999)Plant distribution in relation to soil of reclaimed lands on the west coast of Korea. J Plant Biol42:279-286.

Moffett KB, Gorelick SM, McLaren RG, Sudicky EA. (2012) Salt marsh ecohydrological zonation due to heterogeneous vegetationgroundwater-surface water interactions. Water Resour Res 48:W02516.

Morris JT, Sundareshwar PV, Nietch CT, Kjerfve B, Cahoon DR. (2002) Response of coastal wetlands to rising sea level. Ecology 83:2869-2877. 
Morzaria-Luna H, Callaway JC, Sullivan G, Zedler JB. (2004) Relationship between topographic heterogeneity and vegetation patterns in a Californian salt-marsh. J Veg Sci 15:523-530.

Munns R, Tester M. (2008) Mechanisms of salinity tolerance. Annu Rev Plant Biol 59:651-681.

Murphy BP, Bowman DMJS. (2012) What controls the distribution of tropical forest and savanna? Ecol Lett 15:748-758.

Myeong HH, Lee JS, Jeon JY, Song MS. (2011) Study on creation method of green space for port ecosystem using the halophytes. J Korean Soc Coast Ocean Eng 23:50-56.

Naidoo G, Kift J. (2006) Responses of the saltmarsh rush Juncus kraussii to salinity and waterlogging. Aquat Bot 84:217-225.

Noe GB, Zedler JB. (2000) Differential effects of four abiotic factors on the germination of salt marsh annuals. Am J Bot 87:1679-1692.

Olff H, Bakker JP, Fresco LFM. (1988) The effect of fluctuations in tidal inundation frequency on salt-marsh vegetation. Vegetatio 78:13-19.

Omer LS. (2004) Small-scale resource heterogeneity among halophytic plant species in an upper salt marsh community. Aquat Bot78:337-348.

Partridge TR, Wilson JB. (1988) Vegetation patterns in salt marshes of Otago, New Zealand. New Zeal J Bot 26:497-510.

Pennings SC, Grant MB, Bertness MD. (2005) Plant zonation in low-latitude salt marshes: disentangling the roles of flooding, salinity and competition. J Ecol 93:159-167.

Pennings SC, Callaway RM. (1996) Impact of parasitic plant on the structure and dynamics of salt marsh vegetation. Ecology 77:1410-1419.

Pennings SC, Bertness MD. (1999) Using latitudinal variation to examine effects of climate on coastal salt marsh pattern and process. Current Topics in Wetland Biogeochemistry3:100-111.

Pennings SC, Callaway RM. (1992) Salt marsh plant zonation: the relative importance of competition and physical factors. Ecology73:681-690.

Pennings SC, Selig ER, Houser LT, Bertness MD. (2003) Geographic variation in positive and negative interactions among salt marsh plants. Ecology 84:1527-1538.

Phleger CF. (1971) Effect of salinity on the growth of a salt marsh grass. Ecology 52:908-911.

Pidwirny MJ. (1990) Plant zonation in a brackish tidal marsh: Descriptive verification of resource-based competition and community structure. Can J Bot68:1689-1697.

Pielou EC, Routledge RD. (1976)Salt marsh vegetation: Latitudinal gradients in the zonation patterns. Oecologia24:311-321.

Pomeroy LR, Wiegert RG. (1981) The ecology of a salt marsh. Ecological Studies Series, vol. 38. Springer-Verlag Inc., New York, NY.

Rabinowitz D. (1978) Early growth of mangrove seedlings in Panamá, and an hypothesis concerning the relationship of dispersal and zonation. J Biogeogr5:113-133.

Rand TA. (2000) Seed dispersal, habitat suitability and the distribution of halophytes across a salt marsh tidal gradient. J Ecol88:608-621.

Reed DJ. (1995) The response of coastal marshes to sea-level rise: Survival or submergence?Earth Surf Proc Land 20:39-48.

Reimann C, Breckle SW. (1995) Salt tolerance and ion relations of Salsola kali L.: differences between ssp. tragus(L.) Nyman and ssp. ruthenica (Iljin) Soó. New Phytol 130:37-45.

Rogel Já, Ariza FA, Silla RO. (2000) Soil salinity and moisture gradients and plant zonation in Mediterranean salt marshes of southeast Spain. Wetlands20:357-372.

Rogel Já, Silla RO, Ariza FA. (2001) Edaphic characterization and soil ionic composition influencing plant zonation in a semiarid Mediterranean salt marsh. Geoderma99:81-98.

Roman CT, Niering WA, Warren RS. (1984)Salt marsh vegetation change in response to tidal restriction. Environ Manage8:141-150. 
Sánchez JM, Izco J, Medrano M. (1996) Relationships between vegetation zonation and altitude in a salt-marsh system in northwest Spain. J Veg Sci 7:695-702.

Sanderson EW, Foin TC, Ustin SL. (2001) A simple empirical model of salt marsh plant spatial distribution with respect to a tidal channel network. Ecol Model 139:293-307.

Sanderson EW, Ustin SL, Foin TC. (2000) The influence of tidal channels on the distribution of salt marsh plant species in Pataluma Marsh, CA, USA. Plant Ecol 146:29-41.

Scheffer M. (2009) Alternative stable states and regime shifts in ecosystems, in The Princeton guide to ecology, edited by SA Levin, pp. 395406, Princeton University Press, Princeton.

Scheffer M, Carpenter S, Foley JA, Folke C, Walker B. (2001) Catastrophic shifts in ecosystems, Nature413:591-596.

Schröder A, Persson L, de Roos AM. (2005) Direct experimental evidence for alternative stable states: a review. Oikos 110:3-19.

Shumway SW, Bertness MD. (1992) Salt stress limitation of seedling recruitment in a salt marsh plant community. Oecologia92:490-497.

Serag MS. (1999)Ecologyof four succulent halophytesin the Mediterranean coast of Damietta, Egypt. Estuar Coast Shelf S49 (Supplement A):29-36.

Silander JA, Antonovics J. (1982) Analysis of interspecific competition in a coastal plant community, a perturbation approach. Nature298:557560.

Silliman BR, Zieman JC. (2001) Top-down control of Spartina alterniflora production by periwinkle grazing in a Virginia salt marsh. Ecology82:2830-2845.

Silvestri S, Defina A, Marani M. (2005) Tidal regime, salinity and salt marsh plant zonation. Estuar Coast Shelf S62:119-130.

Simas T, Nunes JP, Ferreira JG. (2001) Effects of global climate change on coastal salt marshes. Ecol Model 139:1-15.

Snow AA, Vince SW. (1984) Plant zonation in an Alaskan salt marsh. II. An experimental study of the role of edaphic conditions. J Ecol 72:669684.

Stachowicz JJ, Hay ME. (1999) Reducing predation through chemically mediated camouflage: indirect effects of plant defenses on herbivores. Ecology80:495-509.

Tessier M, Vivier J-P, Ouin A, Gloaguen J-C, Lefeuvre J-C. (2003) Vegetation dynamics and plant species interactions under grazed and ungrazed conditions in a western European salt marsh. Acta Oecol 24:103-111.

Tilman D. (1984) Plant dominance along an experimental nutrient gradient. Ecology 65:1445-1453.

Tilman D. (1988) Plant strategies and the dynamics and structure of plant communities. Princeton University Press, Princeton, New Jersey, USA.

Touchette BW. (2006) Salt tolerance in a Juncus roemerianus brackish marsh: Spatial variations in plant water relations. J Exp Mar Biol Ecol $337: 1-12$.

Touchette BW, Smith GA, Rhodes KL, Poole M. (2009) Tolerance and avoidance: Two contrasting physiological responses to salt stress in mature marsh halophytes Juncus roemerianus Scheele and Spartina alterniflora Loisel. J Exp Mar Biol Ecol 380:106-112.

Ungar IA. (1998)Are biotic factors significant in influencing the distribution of halophytes in saline habitats? Bot Rev 64:176-199.

Ungar IA. (1978) Halophyte seed germination. Bot Rev 44:233-264.

van Wijnen HJ, Bakker JP. (1999) Nitrogen and phosphorous limitation in a coastal barrier salt marsh: the implications for vegetation succession. J Ecol 87:265-272. 
van Wesenbeeck BK, van de Koppel J, PMJ Herman and TJ Bouma. (2008) Does scale-dependent feedback explain spatial complexity in saltmarsh ecosystems? Oikos 117:152-159.

Vince SW, Snow AA. (1984) Plant Zonation in an Alaskan Salt Marsh: I. Distribution, Abundance and Environmental Factors. J Ecol72:651-667. Wang H, Hsieh YP, Harwell MA, Huang W. (2007) Modeling soil salinity distribution along topographic gradients in tidal salt marshes in Atlantic and Gulf coastal regions. Ecol Model 201:429-439.

Wang C, Temmerman S. (2013) Does bio-geomorphic feedback lead to abrupt shifts between alternative landscape states?: an empirical study on intertidal flats and marshes. J geophys Res: Earth Surf 118:229-240.

Warren RS,Niering WA. (1993)Vegetation change on a northeast tidal marsh: Interaction of sea-level rise and marsh accretion. Ecology74:96103.

Wilson JB, Agnew ADQ. (1992) Positive-feedback switches in plant communities. Adv Ecol Res 23:263-336.

Wilson SD,Keddy PA. (1985) Plant zonation on a shoreline gradient: physiological response curves of component species. J Ecol73:851-860.

Wilson SD, Tilman D. (1993) Plant competition and resource availability in response to disturbance and fertilization. Ecology 74:599-611.

Woerner LS, Hackney CT. (1997) Distribution of Juncus roemerianus in North Carolina tidal marshes: the importance of physical and biotic variables. Wetlands 17:284-291.

Wolcott DL, O'Connor NJ. (1992) Herbivory in crabs: adaptations and ecological considerations. Am Zool32:370-381.

Wood SW, Bowman DMJS. (2012) Alternative stable states and the role of fire-vegetation-soil feedbacks in the temperate wilderness of southwest Tasmania.Landscape Ecol 27:13-28.

Xin P, Gibbes B, Li L, Song Z, Lockington D. (2010)Soil saturation index of salt marshes subjected to spring-neap tides: a new variable for describing marsh soil aeration condition. Hydrol Process24:2564-2577.

Xin P, Kong J, Li L, Barry DA. (2013)Modelling of groundwater-vegetation interactions in a tidal marsh.Adv Water Resour 57:52-68.

Zedler JB, Callaway JC, Desmond J, Vivian-Smith G, Williams G, Sullivan G, Brewster A, Bradshaw B. (1999) Californian salt marsh vegetation: an improved model of spatial pattern. Ecosystems 2:19-35. 